\title{
Správa výukových kurzů v systému Moodle
}

\author{
Petr Soukup \\ Department of Mapping and Cartography \\ Faculty of Civil Engineering, CTU in Prague \\ E-mail: soukup@fsv.cvut.cz
}

\section{Úvod}

S výukovým procesem je spojena řada nezbytných administrativních úkonů, které jsou značně časově náročné a zabírají omezenou kapacitu vyučujících. Patří sem činnosti jako evidence studijních aktivit studentů, zadávání a hodnocení úkolů, zadávání a hodnocení testů znalostí studentů, elektronická komunikace se studenty, atd. Současně s rozvojem informačních technologií se prohlubuje trend poskytnout studentům pro studium větší volnost v čase i prostoru. Se všemi těmito aspekty moderní výuky se snaží pomoci programové nástroje označované často zkratkou CMS (Course Management System).

\section{E-learning a ČVUT}

ČVUT sleduje a vyvíjí aktivity v oblasti e-learningu již delší dobu [Navrátil 2006], ale zatím podle mého názoru poněkud hledá jeho optimální využití ve výuce. Počátky konkrétních řešení spadají zhruba do období přelomu tisíciletí a jsou spojeny se systémem WebCT. Bohužel z důvodu rostoucích licenčních poplatků bylo záhy od využívání tohoto systému upuštěno s tím, že jako jeho nástupce byl vybrán systém ClassServer firmy Microsoft. Pro zabezpečení náročných a rozsáhlých potřeb výuky na vysokých školách je však v současné době tento systém podle mého názoru málo vhodný. Přes nákladné snahy o jeho integrování do fakultního informačního systému nedoznal podle mých informací většího praktického rozšíření.

Jako jedna z perspektivních variant dalšího směřování v oblasti e-learningu se jeví možnost používat pro správu výukových kurzů systémy založené na GNU licenci. Jedním z nejznámějších představitelů této kategorie je systém Moodle. V současné době vznikají na ČVUT první výukové kurzy provozované $\mathrm{v}$ systému Moodle. Některé z nich jsou dostupné na portálu ČVUT, věnovaném studijním podkladům př́stupným po internetu:

http://ocw.cvut.cz/moodle/.

\section{Moodle - charakteristika}

Moodle je programový systém spadající do kategorie CMS. Jako takový jednak integruje do jednotného prostředí rozmanité nástroje a formy používané při výuce a jednak podporuje administrativní zabezpečení výuky.

Moodle je softwarový balík určený pro podporu prezenční i distanční výuky prostřednictvím online kurzů dostupných na WWW. Moodle je software volně šiřitelný na základě GNU licence s otevřeným PHP kódem. Běží na každém operačním systému, který podporuje PHP (Unix, Linux, Windows, Mac OS X, Netware). Všechna data jsou ukládána v jediné databázi. 
Největší podpora je poskytována databázím MySQL a PostgreSQL, nicméně lze použít i jiné databáze (Oracle, Access, Interbase, ODBC atd).

Další informace lze získat na webových stránkách http://moodle.cz/ nebo http://moodle.org , kde se lze také dočíst o původu slova Moodle:

Slovo Moodle bylo původně akronymem pro Modular Object-Oriented Dynamic Learning Environment (Modulární objektově orientované dynamické prostředí pro výuku). Lze ho také považovat za sloveso, které popisuje proces líného bloumání od jednoho k druhému, dělání věcí podle svého, hravost, která často vede $\mathrm{k}$ pochopení problému a podporuje tvořivost. $\mathrm{V}$ tomto smyslu se vztahuje jak k samotnému zrodu Moodlu, tak k př́stupu studenta či učitele $\mathrm{k}$ výuce v on-line kurzech.

Systém Moodle se úspěšně prosazuje na řadě vysokých školách v ČR. Na Karlově univerzitě se systém Moodle systematicky využívá již několik let a v současné době obsluhuje několik desítek výukových kurzů (http://div.cuni.cz/). Také ve světě se začíná Moodle výrazně prosazovat. Britská Open University (http://www.open.ac.uk/) se rozhodla vybudovat rozsáhlý systém kurzů s využitím systému Moodle. Inovace vyvinuté v rámci projektu budou dostupné celé komunitě uživatelů tohoto systému.

\section{Moodle - možnosti}

V dalším textu je uveden přehled základních vlastností systému Moodle.

\section{Role uživatelů}

Systém rozlišuje tyto uživatele (typy kont):

- administrátor - je určen během instalace, spravuje systém jako celek, určuje tvưrce kurzů,

- tvůrce kurzu - zakládá kurzy, určuje učitele pro kurzy,

- učitel - edituje kurz a řídí jeho výuku, zapisuje a odhlašuje studenty z kurzu,

- student - studuje kurz, spravuje svůj osobní profil,

- host - student, který může nahlédnout do kurzu, ale nemá možnost zasahovat aktivním způsobem do jeho chodu.

Účastníci výukového kurzu mají v systému Moodle vytvořený účet. Účet si mohou studenti vytvářet sami (je-li to povoleno) nebo jim může (př́ípadně musí) účet vytvořit učitel a to bud' dávkovým způsobem celé skupině studentů najednou či interaktivně jednotlivcům. Účet je chráněný heslem, které se zadává a ověřuje při každém přihlašování do kurzu. Ověření hesla lze provádět několika mechanismy (vưči lokálně uloženému heslu, proti serverům LDAP, IMAP, POP3, NNTP, případně vůči libovolné externí databázi - je implementována podpora certifikátů SSL a TLS).

Učitel může pro každý kurz stanovit "klíč k zápisu", aby do něj měli přístup pouze oprávnění studenti. Tento klíč sdělí studentům (osobně, soukromým e-mailem apod.) a ti jej zadají při 
prvním přihlášení do kurzu.

\section{Uspořádání kurzu}

Činnost výukového kurzu je poskládána z jednotlivých modulů. Základní moduly jsou:

Studijní materiály - lze využít jakéhokoli materiálu dostupného v elektronické formě (texty, prezentace, Flash, video nebo zvukové soubory ap.). Materiály lze nahrát na server Mooodlu nebo je odkazovat jako externí zdroje na internetu. V kurzu lze pracovat s webovými aplikacemi a předávat jim data.

Úkoly - lze stanovit termín odevzdání a maximální počet bodů. Výsledkem úkolu může být soubor v libovolném formátu (do zadané velikosti), který studenti uloží na serveru. Odevzdaný soubor je opatřen časem odevzdání. Opožděné odevzdání lze umožnit, je však jasně zvýrazněno případné opožděné odevzdání. Lze navolit, zda již ohodnocenou úlohu lze znovu odevzdat - opravit. Informace o ohodnocení úlohy je studentovi automaticky odeslána emailem.

Fórum - podporuje komunikaci mezi účastníky kurzu. Jsou k dispozici různé typy fór, např. učitelské, aktuální zprávy z kurzu, veřejné fórum nebo fórum umožňující každému uživateli založit pouze jedno téma diskuse. Nové příspěvky mohou být automaticky rozesílány emailem.

Test - pro ověřování znalostí studentů. Existuje několik variant testů. Otázky a odpovědi lze náhodně míchat, lze navolit časové intervaly, kdy lze test spustit, volitelně lze zobrazovat správné odpovědi. Testy mohou obsahovat řadu typů otázek (výběr jedné nebo více odpovědí, krátké tvořené odpovědi, přiřazovací otázky, numerické úlohy včetně tolerance, otázky typu $\mathrm{Ano} / \mathrm{Ne})$.

Mezi další užitečné moduly patř́i např. moduly Chat, Dotazník nebo Workshop.

Výukový kurz může být uspořádán týdenním, tématickým nebo diskusním způsobem. Nástroje kurzu poskytují rozsáhlé možnosti sledování a zaznamenávání činnosti uživatelů. Obsah kurzu lze zálohovat a přenášet na jiné servery se systémem Moodle.

\section{Moodle a IGS}

Na katedře Mapování a kartografie se zabývám výukou předmětu Interaktivní grafické systémy (IGS) [Soukup, Žofka, 2005]. Předmět je rozložen do dvou semestrů. Jeho hlavním cílem je naučit studenty základům práce s grafickými editory, které budou dále využívat v navazujících odborných předmětech. V prvním semestru se studenti seznámí s obecným grafickým systémem MicroStation, druhý semestr je věnován specifičtěji zaměřenému systému Kokeš. Oba předměty jsou doplněny navazujícími volitelnými předměty, které prohlubují získané základní znalosti.

Poslední semestr jsme výuku jednoho z těchto předmětů realizovali pomocí systému Moodle. Výuky se zúčastnilo cca 40 studentů. Zkušenosti s využitím systému jsou vesměs pozitivní a proto od přístích semestrů počítáme s jeho nasazením v rámci obou základních předmětům IGS1 i IGS2 (každý z nich navštěvuje přibližně 100 studentů). 
Při hodnocení našich praktických zkušeností se systémem Moodle se zaměřím na několik aspektů, které mohou mít obecnější charakter.

\section{Studentská konta}

Pro aktivní práci ve výukovém kurzu musí mít student v systému Moodle založené osobní konto (účet). Jednoduchá generace studentských kont je však nezbytná podmínka pro větší využití systému Moodle ve výuce. Pokud mají názvy kont odpovídat jménům studentů, je potřeba konta předem připravit. Všechny informace potřebné pro zakládání kont jsou přitom již evidovány ve fakultním informačním systému KOS (KOmponenta Studium) a nemusí se tedy znovu zjištovat či digitalizovat. V současné době však není ještě zcela zautomatizován proces využití těchto informací pro tvorbu kont. Existuje sice převodní program KOSMood [Duben 2006], ale vstupní data, která se generují z databáze systému KOS, se nám nepodařilo zajistit. Použili jsme proto dávkový způsob zakládání kont, který je integrovaný v systému Moodle, a při kterém se všechny potřebné údaje přebírají z připraveného textového souboru v zadaném formátu. Na náš požadavek byl tento typ výstupu doplněn do systému KOS. V současné době je potřeba ještě provést jistou ruční úpravu tohoto výstupu a následně již lze nechat vygenerovat příslušná studentská konta. Tento postup může realizovat každý učitel kurzu systému Moodle, který má přístup do databáze KOS. Je zřejmé, že při větším nasazení systému Moodle ve výuce by bylo potřeba tvorbu studentských kont a zařazování studentů do kurzů ještě více usnadnit.

\section{Studijní materiály}

Studijní materiály tvoří základ každého výukového kurzu. V systému Moodle mohou být v textovém formátu, ve formátu HTML nebo mohou být dostupné ve formě webového odkazu. Studijní materiály v kurzu IGS2 jsme vytvořili ve formátu typu wiki, z něhož jsou soubory automaticky převáděny do formátu HTML. Tvorba takových dokumentů je jednodušší a výsledné texty jsou unifikovanější. Jistou nevýhodou je, že ve světě internetu existuje více formátů typu wiki navzájem se lišících formátovacími možnostmi a použitými značkami. Filosofie wiki dokumentů povoluje jejich veřejnou editaci. Tento princip podporuje volitelně i wiki systému Moodle.

Stávající studijní materiály kurzu IGS2 považujeme za poněkud strohé a chystáme jejich oživení. Vedle běžných prvků jako obrázky nebo ikony uvažujeme o vytvoření sady ozvučených animací, které by názorně zachycovaly obtížnější etapy práce s grafickým systémem. Studium by tak získalo pro studenty poutavější formu, bylo by efektivnější a byla by tak podpořena i určitá forma distanční výuky.

\section{Oprava úkolů}

Během semestru studenti průběžně vypracovávají jednotlivé úkoly a odevzdávají je dohodnutým způsobem ve formě souborů. V případě předmětu IGS1 i IGS2 se jedná o kontrolu zhruba 100 souborů každý týden. Kontrola patří k časově nejnáročnějším a nejméně oblíbeným činnostem spojeným s výukou. Jakákoli pomoc v této oblasti je proto učiteli velmi vítána. 
Systém Moodle nabízí některé nástroje, které mohou opravu odevzdaných úkolů zpřehlednit a usnadnit. Ve výuce kurzu IGS2 jsme pro opravy úkolů použili následující pravidla. Pro odevzdání každého úkolu byl stanoven termín a bylo sledováno a př́padně bodově penalizováno jeho nedodržení. Studenti mohli úkol před vypršením termínu opakovaně opravovat do té doby, dokud nebyl zkontrolován a ohodnocen vyučujícím. Poté již úkol nebylo možné opravit. Hodnocení úkolů mohl vyučující doplnit i slovním zdůvodněním. Po ohodnocení úoklu učitelem byl automaticky př́slušnému studentovi odeslán o této skutečnosti e-mail s odkazem na stránku s hodnocením. Vedlejší výhodou tohoto způsobu odevzdávání a hodnocení úkolů je, že studenti mají přístup k výsledkům a hodnocení pouze svých vlastních výtvorů (nikoli k výsledkům spolužáků).

Podle našich zkušeností nám systém Moodle velmi usnadnil opravy studentských úkolů. Domnívám se, že u předmětů, ve kterých studenti často odevzdávají výsledky zadaných úkolů v digitální podobě, jsou možnosti systému Moodle v této oblasti jedním z hlavních argumentů pro jeho nasazení ve výuce.

\section{Testování studentů}

Testování znalostí studentů tvoří důležitou součást každé výuky. U počítačově podporovaných kurzů to platí dvojnásob [Soukup 2004].

Systém Moodle umožňuje pracovat s mnoha typy testů, jejichž seznam lze dále rozšiřovat. Na našem pracovišti jsme v minulých letech vyvinuli vlastní programový systém na testování studentů. Systém úspěšně používáme a průběžně zdokonalujeme již několik let. Plánujeme proto implementovat tento testovací modul do prostředí systému Moodlu tak, aby se stal jeho integrální součástí, tj. aby např. výsledky testu byly zahrnuty mezi ostatní hodnocení studenta.

\section{Závěr}

Domnívám se, že CMS nástroje mají budoucnost a mohou přispět k zefektivnění výuky. Moodle je svojí koncepcí vhodný kandidát pro nasazení v akademické sféře. Jeho užívání není spojeno s licenčními poplatky a dostupnost zdrojových kódů umožňuje vlastní vývoj jeho dalších rozšíření. V současné době jako jistou komplikaci při jeho větším nasazení v našich podmínkách vidím jeho nedokonalou provázanost s fakultním informačním systémem KOS, což komplikuje automatizaci zakládání studentských kont. Uvedený nedostatek by ale mělo jít vcelku snadno odstranit a pak by mohl systém Moodle nalézt zajímavé uplatnění ve výuce rady př̀edmětů.

Ohledně výuky předmětu Interaktivní grafické systémy uvažujeme o rozšîrení a oživení výukových textů o multimediální prvky. Obtížnější postupy práce s grafickými systémy bychom rádi zpracovali do podoby animovaných sekvencí doprovázených mluveným komentářem. 


\section{Literatura}

1. Soukup, P. (2004): E-learning and Checking of Study Effectiveness by Testing. In: Proceedings of Conference ICETA 2004: Information and Telecommunications Technologies in Education, Košice, Slovak Republic, 16.9. - 18.9.2004, p. 371-375, ISBN 80-89066-85-2

2. Soukup, P., Žofka, P. (2005): Výuka interaktivních grafických systémů na oboru Geodézie a kartografie Stavební fakulty ČVUT Praha. In: Sborní referátů (CD ROM): 16. kartografická konference Mapa v informační společnosti, Brno, 7.9. - 9.9.2005, str. 209-213. ISBN 80-7231-015-1

3. Duben, S.(2006): Automatizace přihlašování do Moodle. In: sborník konference Belcom - 06 Spolupráce univerzit při efektivní tvorbě a využívání vzdělávacích zdrojů.str. 3-8. CDROM

4. Navrátil, J. (2006): E-learning na ČVUT. In: sborník konference Belcom 06 - Spolupráce univerzit při efektivní tvorbě a využívání vzdělávacích zdrojů.str. 77-80. CDROM 